\title{
Gerstmann-Sträussler-Scheinker disease revisited: accumulation of covalently-linked multimers of internal prion protein fragments
}

\author{
Laura Cracco ${ }^{1}$, Xiangzhu Xiao ${ }^{2 \dagger}$, Satish K. Nemani ${ }^{1 \dagger}$, Jody Lavrich ${ }^{1}$, Ignazio Cali ${ }^{1,3}$, Bernardino Ghetti ${ }^{4}$, Silvio Notari ${ }^{1}$,
} Witold K. Surewicz ${ }^{2}$ and Pierluigi Gambetti ${ }^{i^{*}}$ (D)

\begin{abstract}
Despite their phenotypic heterogeneity, most human prion diseases belong to two broadly defined groups: Creutzfeldt-Jakob disease (CJD) and Gerstmann-Sträussler-Scheinker disease (GSS). While the structural characteristics of the disease-related proteinase K-resistant prion protein (resPrPD) associated with the CJD group are fairly well established, many features of GSS-associated resPrPD are unclear. Electrophoretic profiles of resPrPD associated with GSS variants typically show $6-8 \mathrm{kDa}$ bands corresponding to the internal PrP fragments as well as a variable number of higher molecular weight bands, the molecular nature of which has not been investigated. Here we have performed systematic studies of purified resPrPD species extracted from GSS cases with the A117V (GSS A117V) and F198S (GSS ${ }^{\mathrm{F} 1985}$ ) PrP gene mutations. The combined analysis based on epitope mapping, deglycosylation treatment and direct amino acid sequencing by mass spectrometry provided a conclusive evidence that high molecular weight resPrPD species seen in electrophoretic profiles represent covalently-linked multimers of the internal $\sim 7$ and $\sim 8 \mathrm{kDa}$ fragments. This finding reveals a mechanism of resPrP ${ }^{\mathrm{D}}$ aggregate formation that has not been previously established in prion diseases.
\end{abstract}

Keywords: Creutzfeldt-Jakob disease, Prion protein, Aggregate formation, Multimers, Mass spectrometry, Epitope mapping

\section{Introduction}

A well-known feature of human prion diseases is the presence of three distinct etiologic forms - sporadic, inherited and acquired by infection. A further complicating factor is the great phenotypic variability within each of these etiologically distinct groups. For example, the sporadic form alone encompasses seven major disease phenotypes [15, $16,39]$, and many different variants have been reported for inherited prion diseases $[20,21]$. This phenotypic variability is believed to be directly related to (and likely encoded in) distinct strains of the disease-related prion protein $\left(\operatorname{PrP}{ }^{\mathrm{D}}\right)$. However, the nature and extent of specific

* Correspondence: pxg13@case.edu

${ }^{+}$Xiangzhu Xiao and Satish K. Nemani contributed equally to this work.

${ }^{1}$ Department of Pathology, Case Western Reserve University, Cleveland, $\mathrm{OH}$, USA

Full list of author information is available at the end of the article structural differences between phenotype-specific $\operatorname{PrP}^{\mathrm{D}}$ strains remain poorly understood [15].

According to the classification based on electrophoretic profiles of the proteinase $\mathrm{K}(\mathrm{PK})$-resistant $\operatorname{Pr} \mathrm{P}^{\mathrm{D}}\left(\right.$ resPrP $\left.\mathrm{P}^{\mathrm{D}}\right)$, most cases of sporadic and inherited prion diseases fall into two broadly defined groups: Creutzfeldt-Jakob disease (CJD) and Gerstmann-Sträussler-Scheinker disease (GSS). CJD is characterized by the presence of relatively large resPrP $\mathrm{P}^{\mathrm{D}}$ fragments which, depending on the $\mathrm{N}$-terminus, are classified as type 1 (typically starting at residue G82) and type 2 (starting at residue S97) $[15,26]$. Both fragment types extend to the C-terminus and include the glycosylphosphatidylinositol (GPI) anchor [16, 39]. Electrophoretic profiles of these fragments include bands of approximately 30 and $27 \mathrm{kDa}$ (representing the di- and mono-glycosylated forms) as well as bands of 21 and 19 $\mathrm{kDa}$ which represent the un-glycosylated form in $\operatorname{resPrP}^{\mathrm{D}}$ types 1 and 2 , respectively. Collectively, these three 
resPrP ${ }^{\mathrm{D}}$ fragments are commonly referred to as $\operatorname{PrP} 27-$ 30 [8]. A remarkably different electrophoretic profile is observed in GSS, where the most prominent and by far best characterized resPrP $\mathrm{P}^{\mathrm{D}}$ species is a $6-8 \mathrm{kDa}$ fragment encompassing internal residues from within the $\sim 70-150$ region [12, 25, 27, 33, 34]. Higher molecular weight (hmw) bands of variable estimated molecular weights have also been reported, occasionally prompting the hypothesis that they represent multimers. However, the molecular nature of the PrP fragments giving rise to these bands remains enigmatic [12, 17, 23].

To bridge this gap, here we have performed detailed analysis of purified resPrP $\mathrm{P}^{\mathrm{D}}$ preparations from GSS cases harboring the A117V (GSS ${ }^{\mathrm{A} 117 \mathrm{~V}}$ ) and F198S $\left(\mathrm{GSS}^{\mathrm{F} 198 \mathrm{~S}}\right.$ ) PrP mutations. Our data demonstrate that high molecular weight species seen in electrophoretic profiles of GSS ${ }^{\mathrm{A} 117 \mathrm{~V}}$ and $\mathrm{GSS}^{\mathrm{F} 198 \mathrm{~S}}$ resPrP ${ }^{\mathrm{D}}$ represent covalently-linked multimers of the same internal PrP fragments that are present (as monomers) in the $\sim 7$ and $\sim 8 \mathrm{kDa}$ bands.

\section{Materials and methods}

\section{Reagents and antibodies}

$\beta$-mercaptoethanol, Dithiothreitol, Laemmli Sample Buffer, Non-fat dry milk, Sodium dodecyl sulfate (SDS), Tris Buffered Saline (TBS), Tris/Glycine/SDS buffer, Tris/Glycine Buffer, Tween 20 and 15\% Criterion Tris- $\mathrm{HCl}$ polyacrylamide precast gels were purchased from Bio-Rad Laboratories (Hercules, CA, USA). Benzonase, Calcium chloride, Complete Ultra Protease Inhibitor Cocktail Tablets, Dulbecco's PBS (D-PBS), Kodak Biomax MR and XAR films, $\mathrm{NaCl}$, Nonidet P-40, N-Lauroylsarcosine sodium salt solution (Sarkosyl), Phenylmethanesulfonyl fluoride (PMSF), Polyvinylidene difluoride (PVDF) membrane (Immobilon-P), Proteinase K, Sodium deoxycholate and Tris- $\mathrm{HCl}$ came from MilliporeSigma (Burlington, MA, USA) whereas Ethylenediaminetetraacetic acid (EDTA) from Promega (Madison, WI, USA). Glycerol-free PNGase F was from New England Biolabs Inc. (Ipswich, MA, USA); Acetonitrile, Colloidal Blue Staining Kit, Ethanol, Formic Acid, 8 M Guanidine-HCl Solution, Methanol, Pierce ECL 2 Western Blotting Substrate and Trypsin from Thermo Fisher Scientific Inc. (Waltham, MA, USA).

The following antibodies (Abs) were used in the study: 8B4 (to human PrP residues 36-43) [22], SAF32 (to human octarepeat region) [14] (Cayman Chemical, Ann Arbor, MI, USA), 3F4 (to human PrP residues 106-110) [19, 42], F89 (to human PrP residues 139-142) (Thermo Fisher Scientific Inc., Waltham, MA, USA), L42 (to human PrP residues 145-150) [18, 38] (R-Biopharm, AG, Darmstadt, Germany) and SAF70 (to human PrP residues 156-162) [14]. Secondary Ab was sheep anti-mouse IgG, HRP-linked whole antibody (GE Healthcare Life Sciences, Chicago, IL, USA).

\section{Brain tissues}

All frozen brain tissues were obtained from the National Prion Disease Pathology Surveillance Center (NPDPSC). Frontal cortex samples from two cases each of GSS A117V-129V (129MV and 129VV) and F198S-129V (129MV) were used. All cases were used for immunoblotting, but only one case of GSS ${ }^{\mathrm{A117V}}$ and $\mathrm{GSS}^{\mathrm{F} 198 \mathrm{~S}}$, both with 129MV genotype, were used for mass spectrometry. A case of sCJDMV1 was used as control.

\section{Preparation of brain homogenates}

Brain homogenates $(\mathrm{BH})$ were prepared as previously described [13].

\section{Proteinase $\mathrm{K}$ digestion}

Samples were incubated for $1 \mathrm{~h}$ at $37^{\circ} \mathrm{C}$ with different amounts of PK, as follows: GSS ${ }^{\mathrm{A} 117 \mathrm{~V}}$ : purified $\operatorname{PrP}^{\mathrm{D}}(\mathrm{PK}$ $2 \mathrm{U} / \mathrm{ml}) ; \mathrm{GSS}^{\mathrm{F}}{ }^{1985}$ : $\mathrm{BH}(\mathrm{PK} 5 \mathrm{U} / \mathrm{ml})$, purified $\operatorname{PrP}^{\mathrm{D}}$ (PK $10 \mathrm{U} / \mathrm{ml}$ ); sCJDMV1: purified $\operatorname{PrP}^{\mathrm{D}}$ (PK $\left.10 \mathrm{U} / \mathrm{ml}\right)$. The reaction was stopped by the addition of $3 \mathrm{mM}$ PMSF.

\section{Epitope mapping}

The optimal PK concentrations and the volumes of purified $\mathrm{GSS}^{\mathrm{F} 198 \mathrm{~S}}, \mathrm{GSS}^{\mathrm{A}}{ }^{117 \mathrm{~V}}$ and $\mathrm{sCJDMV} 1$ resPrP $\mathrm{P}^{\mathrm{D}}$ loaded into the gel were selected to obtain a clear visibility of all the bands with 3F4. Recombinant human PrP full-length (23-231) and truncated (90-231) species were used as molecular weight markers.

\section{Methanol/ethanol precipitation}

Methanol precipitation was performed as previously described [13]. For ethanol precipitation the same procedure was followed with the exception of 9 volumes of pre-chilled ethanol instead of 5 volumes used to dilute the sample.

\section{PrP deglycosylation}

Samples were treated with glycerol-free PNGase F in accordance with manufacturer's instructions.

\section{Electrophoresis and immunoblot}

Protein samples were run on $15 \%$ Criterion Tris- $\mathrm{HCl}$ polyacrylamide precast gels and then subjected to immunoblot $(60 \mathrm{~V}$ for $2 \mathrm{~h})$ using Immobilon-P PVDF membranes. After $1 \mathrm{~h}$ blocking in 5\% non-fat dry milk in TBS with $0.1 \%$ Tween 20 (TBS-T), the membranes were incubated with primary $\mathrm{Ab}$ overnight at $4{ }^{\circ} \mathrm{C}$; they were then washed with TBS-T, incubated for $1 \mathrm{~h}$ at RT with the secondary HRP-conjugated $\mathrm{Ab}$ and then washed again prior to developing by enhanced chemiluminescence reaction using ECL 2 western blotting substrate, as per manufacturer's instructions. Kodak MR and XAR films were used to capture the signal. 


\section{ResPrP $P^{\mathrm{D}}$ purification}

$\operatorname{ResPrP}^{\mathrm{D}}$ purification was performed as reported in Bolton et al. [7] and adapted by Zou et al. [40]. Rotor SW55Ti (Beckman Coulter, Brea, CA, USA) was used for ultracentrifugation.

\section{In-gel trypsin digestion of purified resPrP ${ }^{D}$}

In-gel trypsin digestion was performed according to an established protocol [31]. Briefly, the protein bands of interest (visualized by Colloidal Coomassie blue staining) were excised from the gel, cut into small cubes and destained. The destained gel pieces were then dehydrated and followed by reduction/alkylation step. For digestion, trypsin solution $(15 \mathrm{ng} / \mu \mathrm{l})$ was added and gel pieces were incubated overnight at $37^{\circ} \mathrm{C}$ with shaking. The supernatant was then transferred into a new Eppendorf tube and the remaining peptides in gel pieces were extracted, supernatants were pooled, concentrated and stored at $-80^{\circ} \mathrm{C}$ until analyzed by Nano LC-MS.

\section{Nano LC-MS/MS}

Nanospray LC-MS-MS analysis was performed using an LTQ Orbitrap XL mass spectrometer equipped with nanoelectrospray source (Thermo Scientific, San Jose, CA, USA). Trypsin-digested samples were loaded onto a C-18 trap column (to remove salts) and separated on a C-18 column connected to an emitter. Separation was performed using a Dionex UltiMate 3000 system (Thermo Scientific, San Jose, CA, USA) and a gradient of acetonitrile in water containing $0.1 \%$ formic acid. The flow rate was $300 \mathrm{nl} / \mathrm{min}$. The mass spectrometer was externally calibrated using a Pierce LTQ ESI positive ion calibration solution (Thermo Scientific, catalog number 88322). Full scan experiments were acquired in the $\mathrm{m} / \mathrm{z} 300-1800$ range at a resolution of 30,000 (FWHM at $\mathrm{m} / \mathrm{z} 400$ ). The following source settings were used: spray voltage $=4.2$ $\mathrm{kV}$; capillary temperature $=200^{\circ} \mathrm{C}$. Data-dependent $\mathrm{MS}^{\mathrm{n}}$ $(n=2)$ were acquired at ITMS using collision induced dissociation (CID); the top 14 intense ions were subjected for further fragmentation. Calculation of elemental formulae was performed on the mono-isotopic peak of each ion cluster using Xcalibur software v2.2 with a mass tolerance of 3 to $5 \mathrm{ppm}$. MS/MS raw files were searched using MASCOT Deamon engine against the database containing sequence of human prion protein $129 \mathrm{M} / \mathrm{V}$ with mutation A117V or F198S. Trypsin/P search parameters for Mascot peptide identification included one missed tryptic cleavage, fixed carbamidomethylation (+ $57 \mathrm{Da}, \mathrm{Cys})$, and variable oxidation $(+16 \mathrm{Da}$, Met). Mass tolerances of 2.0 and 1.0 Da were used for parent and monoisotopic fragment ions, respectively. The resulting files generated by MASCOT were used for peptide identification with the constraints that only MASCOT ion scores greater than 10 were considered. The percentage of $129 \mathrm{M}$ and $129 \mathrm{~V} \operatorname{PrP}$ in $\operatorname{res} \operatorname{Pr}^{\mathrm{D}}$ samples was calculated by the spectral counting method [4].

\section{Results}

The characteristics of resPrP $\mathrm{P}^{\mathrm{D}}$ in $\mathrm{GSS}^{\mathrm{F} 198 \mathrm{~S}}$ and $\mathrm{GSS}^{\mathrm{A} 117 \mathrm{~V}}$ were examined and compared with those of sCJDMV1 resPrP ${ }^{\mathrm{D}}$, used as control, by combining epitope mapping with enzymatic deglycosylation on immunoblots of purified resPrP $\mathrm{P}^{\mathrm{D}}$ preparations (Fig. 1). Overall, GSS ${ }^{\mathrm{F} 198 \mathrm{~S}}$ and GSS $^{\mathrm{A} 117 \mathrm{~V}}$ showed similar electrophoretic profiles that were easily distinguishable from the profile of SCJDMV1 (Fig. 1). GSS $^{\mathrm{F} 198 \mathrm{~S}}$ and $\mathrm{GSS}^{\mathrm{A} 117 \mathrm{~V}}$ displayed low mw bands of $\sim 8$ and $\sim 7 \mathrm{kDa}$ as well as two broad bands comprised between 17-20 23-24 kDa for GSS ${ }^{\mathrm{F} 198 \mathrm{~S}}$, and $16-18$ and $22-23 \mathrm{kDa}$ for GSS ${ }^{\text {A117V }}$; additional bands and smears of higher mw were also present more prominently in $\mathrm{GSS}^{\mathrm{F}}{ }^{198 \mathrm{~S}}$ (Fig. 1). By contrast, resPrP $\mathrm{P}^{\mathrm{D}}$ profile in SCJDMV1 included the typical three glycoform bands of $\sim 30, \sim 27$, and $\sim 21 \mathrm{kDa}$ of resPrP $\mathrm{P}^{\mathrm{D}}$ type 1 . Two additional unique characteristics further distinguished GSS ${ }^{\mathrm{A} 117 \mathrm{~V}}$ and GSS ${ }^{\mathrm{F} 198 \mathrm{~S}}$ from sCJDMV1. Virtually all resPrP ${ }^{\mathrm{D}}$ bands associated with these two GSS conditions were readily detected only with Abs to epitopes within the $\operatorname{PrP} \sim 51-150$ region, but not with Abs recognizing more C-terminal epitopes (Fig. 1, panels b-f). Furthermore, GSS ${ }^{\mathrm{A} 117 \mathrm{~V}}$ and $\mathrm{GSS}^{\mathrm{F} 198 \mathrm{~S}} \operatorname{resPrP}^{\mathrm{D}}$ (as well as resPrP $\mathrm{P}^{\mathrm{D}}$ from SCJDMV1) showed no immunoreactivity with 8B4 Ab that recognizes the $\mathrm{N}$-terminal epitope $36-43$ (Fig. 1, panel a). This finding excludes the presence of full length resPrP $\mathrm{P}^{\mathrm{D}}$ in these two GSS variants, and is at variance with the presence of full-length resPrP ${ }^{\mathrm{D}}$ reported in $\mathrm{GSS}^{\mathrm{H} 187 \mathrm{R}}$ [12]. In addition to epitope mapping, a second major distinguishing feature was that, in contrast to $\mathrm{SCJDMV} 1 \mathrm{resPrP}^{\mathrm{D}}$, deglycosylation had no significant effect on the electrophoretic mobility of any of the major $\operatorname{resPrP}^{\mathrm{D}}$ bands observed in $\mathrm{GSS}^{\mathrm{F} 198 \mathrm{~S}}$ and $\mathrm{GSS}^{\mathrm{A} 117 \mathrm{~V}}$, strongly suggesting that $\operatorname{resPrP}^{\mathrm{D}}$ populating these bands is not glycosylated (Fig. 1). In a separate experiment carried out in GSS ${ }^{\mathrm{F} 198 \mathrm{~S}}$, we also observed that the $\operatorname{resPrP}{ }^{\mathrm{D}}$ profile did not change after pretreatment of samples with strong denaturants such as guanidine hydrochloride and urea (Additional file 1: Figure S1). Collectively, these data suggest that at least two hmw bands seen in immunoblots of $\mathrm{GSS}^{\mathrm{A} 117 \mathrm{~V}}$ and $\mathrm{GSS}^{\mathrm{F} 198 \mathrm{~S}} \operatorname{resPrP}^{\mathrm{D}}$ represent covalently-linked multimers of the $\sim 7$ and $\sim 8$ kDa fragments (Fig. 1 and Additional file 1: Figure S1).

To definitely assess whether the higher molecular bands represented multimers (likely covalently-linked) of the $\sim 7$ and $\sim 8 \mathrm{kDa}$ internal fragments, as our epitope mapping and glycosylation study strongly suggested, we performed trypsin in-gel digestion of protein fragments on individual electrophoretic bands of purified resPrP $\mathrm{P}^{\mathrm{D}}$ from GSS ${ }^{\mathrm{A} 117 \mathrm{~V}}$ and GSS $^{\mathrm{F} 198 \mathrm{~S}}(\sim 7,16-18$ and $22-23 \mathrm{kDa}$ in the case of $\mathrm{GSS}^{\mathrm{A} 117 \mathrm{~V}}$ and $~ 8,17-20$ and $23-24 \mathrm{kDa}$ in the case of GSS ${ }^{\mathrm{F198S}}$ ) and did amino acid sequencing using mass spectrometry (Nano LC-MS). 


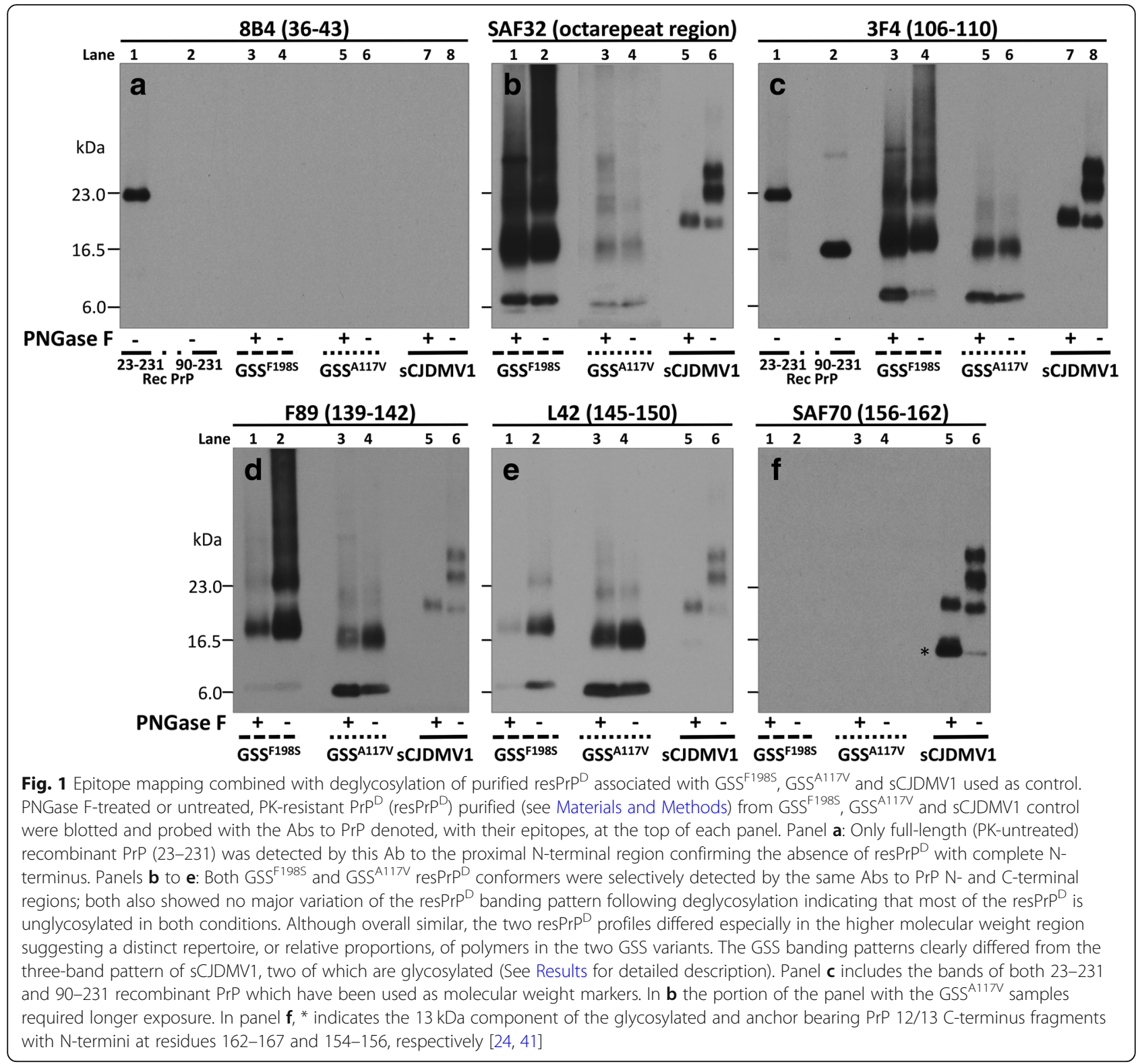

The tryptic digest of the $\sim 7 \mathrm{kDa}$ resPrP $\mathrm{P}^{\mathrm{D}}$ fragment extracted from GSS ${ }^{\mathrm{A} 117 \mathrm{~V}}$ and analyzed by Nano LC-MS revealed the presence of peptides exclusively from the central region of $\operatorname{PrP}$ between residues 78 and 152, with no detectable fragments from other parts of the protein. Trypsin is known to cleave polypeptide chains at the carboxyl side of lysine (K) or arginine (R). As shown in Fig. 2, seven potential trypsin cleavage sites are available within the central region of $\operatorname{PrP}$ between residues 70 and 153. Nano LC-MS analysis of the GSS ${ }^{\mathrm{A} 117 \mathrm{~V}} \sim 7 \mathrm{kDa}$ fragment using the Mascot Deamon searching engine identified fourteen trypsin-generated peptides with $\mathrm{N}$-termini before the first potential trypsin cleavage site, two internal tryptic fragments, and twelve trypsin-generated peptides with $\mathrm{N}$-terminus at the cleavage site following
R136 (Fig. 2a and Additional file 2: Table S1). Altogether, these data demonstrated that in GSS $^{\mathrm{A} 117 \mathrm{~V}}$ the $\sim 7 \mathrm{kDa}$ fragment encompassed residues within the 78-152 region and had ragged $\mathrm{N}$ - and $\mathrm{C}$-termini corresponding to residues $78 / 82 / 85-88$ and $141-152$, respectively. This is generally consistent with previous MALDI-derived data from extracts of PrP amyloid plaque cores, even though our Nano LC-MS analysis (which is more accurate) revealed that the $\mathrm{N}$-terminus of this fragment may extend as far as up to residue 78 versus residue 85 previously reported based on the MALDI analysis [33].

A similar sequencing analysis of the $16-18 \mathrm{kDa}$ and $22-23 \mathrm{kDa}$ bands revealed the presence of essentially identical tryptic fragments, with the exception that the most $\mathrm{N}$-terminal fragment started at residue 82 , and the 


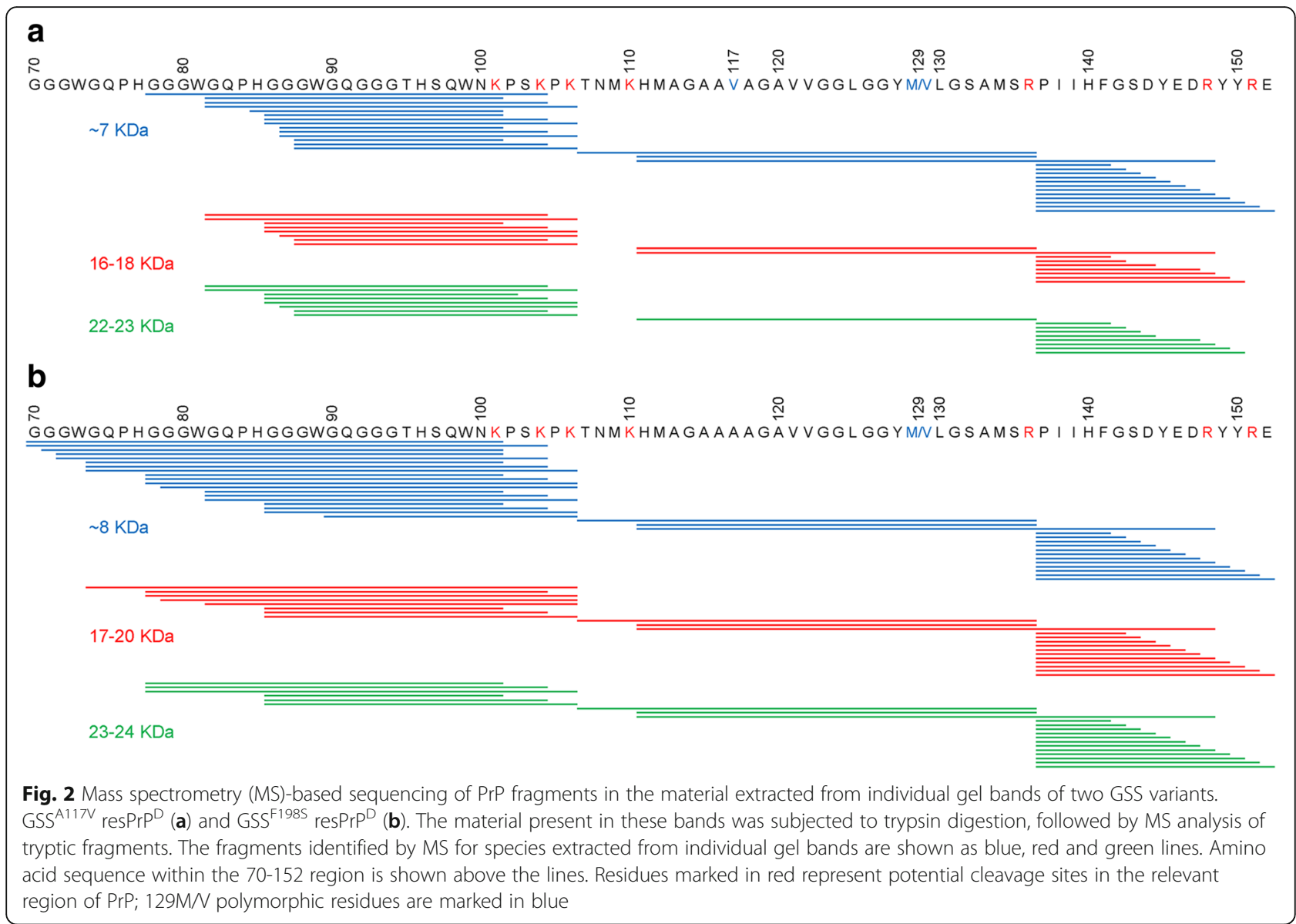

most C-terminal fragment ended at residue 150 (Fig. 2a). Remarkably, we could not detect any tryptic peptides from the region C-terminal to residue 150. Given that numerous peptides from the latter region are readily detectable by MS upon proteolytic digestion of resPrP $\mathrm{P}^{\mathrm{D}}$ from $\mathrm{SCJD}$ cases and mouse prion strains $[1,30]$, one can definitely conclude from these data that the $16-18$ and $22-23 \mathrm{kDa}$ species in $\mathrm{GSS}^{\mathrm{A} 117 \mathrm{~V}}$ resPrP ${ }^{\mathrm{D}}$ indeed represent oligomers (likely trimers and tetramers, respectively) of internal fragments encompassing residues within the 82-150 region. It is of note that fragments in the oligomers are somewhat shorter compared to those in the $\sim 7 \mathrm{kDa}$ band.

MS-based sequencing analysis of protein present in the resPrP $\mathrm{P}^{\mathrm{D}} \sim 8 \mathrm{kDa}$ band from $\mathrm{GSS}^{\mathrm{F} 198 \mathrm{~S}}$ demonstrated that this band contained rugged internal $\operatorname{res} \operatorname{Pr}^{\mathrm{D}}$ fragments from the 70-152 region, with $\mathrm{N}$-termini between residues 70 and 90 and C-termini between residues 141 and 152 (Fig. 2b and Additional file 2: Table S2). Again, MS analysis did not reveal the presence of peptides from parts of $\operatorname{PrP}$ other than the central region between residues 70 and 152. Previous sequencing studies of the $\sim 8$ $\mathrm{kDa}$ fragment (or fragments of similar $\mathrm{kDa}$ ) extracted from PrP amyloid plaques and analyzed by Edman degradation chemistry alone or combined with automated sequencing identified the major $\mathrm{N}$-terminus at residues G58, G74 and G81 while the C-terminus was reported at residue 150 [27, 34, 35].

Very similar internal fragments were identified in higher molecular bands of $17-20$ and $23-24 \mathrm{kDa}$ in GSS $^{\mathrm{F} 198 \mathrm{~S}} \operatorname{resPrP}^{\mathrm{D}}$, with the exception that the longest of these fragments had $\mathrm{N}$-termini at residue 74 and 78 in the $17-20$ and $23-24 \mathrm{kDa}$ bands, respectively (Fig. 2b). Importantly, akin to the finding for $\mathrm{GSS}^{\mathrm{A} 117 \mathrm{~V}} \operatorname{resPrP}{ }^{\mathrm{D}}$, no peptides from the region $\mathrm{C}$-terminal to residue 152 were detected by MS in tryptic digests of protein in these two higher molecular weight bands. Thus, also in GSS $^{\mathrm{F} 198 \mathrm{~S}} \operatorname{resPrP}^{\mathrm{D}}$, the latter bands contained covalently-linked oligomers of the internal $\operatorname{PrP}$ fragments within the $74-78 / 142-152$ region, which, as in GSS $^{\mathrm{A} 117 \mathrm{~V}}$, are somewhat shorter than the $\sim 8 \mathrm{kDa}$ monomer.

Using Nano LC-MS we also determined the relative representation in resPrP $\mathrm{P}^{\mathrm{D}}$ of the $129 \mathrm{M}$ and $129 \mathrm{~V}$ polymorphic forms of the prion protein. Consistent with a previous report, resPrP $\mathrm{P}^{\mathrm{D}}$ from $\mathrm{GSS}^{\mathrm{A} 117 \mathrm{~V}}$ was invariably $100 \% 129 \mathrm{~V}$, with no detectable $129 \mathrm{M}$ polymorph [33]. By contrast, and at variance with a previous report, in $\mathrm{GSS}^{\mathrm{F} 198 \mathrm{~S}} \operatorname{resPrP}^{\mathrm{D}}$, all three bands examined consistently showed the presence of 
both polymorphic variants, with a large dominance (76$88 \%$ ) of the $129 \mathrm{~V}$ polymorph (Fig. 3) [35].

\section{Discussion}

The present results indicate that the mechanism of resPrP $\mathrm{P}^{\mathrm{D}}$ aggregation in GSS ${ }^{\mathrm{A} 117 \mathrm{~V}}$ and $\mathrm{GSS}^{\mathrm{F} 198 \mathrm{~S}}$ involves formation of covalently-linked multimers of the $\sim 7-8 \mathrm{kDa}$ internal fragments. Furthermore, it has been previously shown by Edman degradation chemistry that the 7 and $14 \mathrm{kDa}$ fragments in $\mathrm{GSS}^{\mathrm{H} 187 \mathrm{R}}$ resPrP $\mathrm{P}^{\mathrm{D}}$ share the $\mathrm{N}$-terminus, suggesting that formation of covalently-linked multimers may also

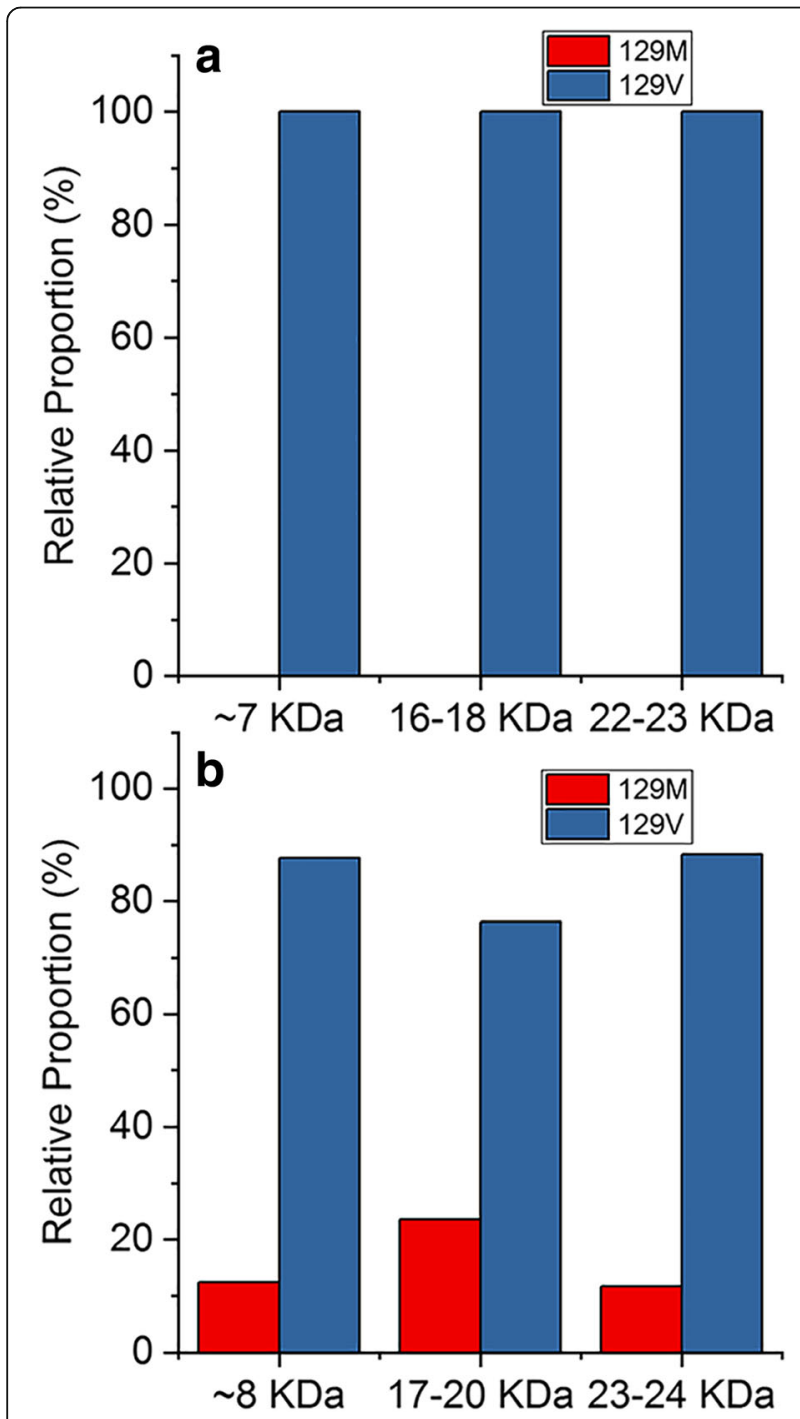

Fig. 3 Relative abundance of $129 \mathrm{M}$ and $129 \mathrm{~V}$ PrP variants in resPrP ${ }^{D}$ associated with GSS ${ }^{A 117 V}$ and GSS ${ }^{\mathrm{F} 198 \mathrm{~S}}$. a: GSSA117V; $\mathbf{b}$ : GSS ${ }^{\mathrm{F} 198 \mathrm{~S}}$. The relative abundance of resPrPD with $M$ or $V$ at residue 129 reflects the representation of the PrP mutation, which is coupled with the $129 \mathrm{~V}$ in both GSS variants. Approximately $10-25 \%$ of resPrPD could be identified as non-mutated (wild type) in GSSF198S while only mutated resPrPD could be detected in GSS ${ }^{A 117 V}$. The relative populations were determined by mass spectrometry using the spectral counting method take place in the latter GSS variant [12]. PrP bands suggestive of dimerization have been reported in cell systems and brain tissues [13, 29]. However, the resistance to PK digestion of these PrP species and, more importantly, their molecular nature have not been determined. In this context, the present data provide the strongest evidence to date for the presence of covalently cross-linked species of resPrP $\mathrm{P}^{\mathrm{D}}$ in prion diseases, suggesting that these previously unrecognized species may play a major role in the pathogenesis of human prion diseases. Of note, covalent crosslinking has been reported for toxic aggregates of $\alpha$-synuclein and $A \beta$ involved in Parkinson's and Alzheimer's diseases, respectively [2, 3, 9, 10, 32].

This novel finding has important implications for understanding phenotypic variability in human prion diseases. Even though resPrP $\mathrm{P}^{\mathrm{D}}$ aggregates associated with both CJD and GSS phenotypes have been shown to be transmissible, the dramatic difference between these species suggests fundamentally different structural mechanisms of prion protein conformational conversion in GSS as compared with those in CJD [6, 28]. Indeed, the absence of the constraints imposed by glycans and the GPI anchor (that are missing in $\sim 7-8 \mathrm{kDa}$ fragments and their covalently-linked multimers) is likely to allow for different types of resPrP $\mathrm{P}^{\mathrm{D}}$ assemblies. A potential structural model for the $\sim 7-8 \mathrm{kDa}$ fragments and their multimers is provided by synthetic amyloid fibrils generated from PrP23-144, a protein matching the sequence of the C-terminally truncated PrP harbored in GSS ${ }^{\text {Y145Stop }}[11,17]$. These synthetic amyloid fibrils adopt a parallel in-register $\beta$-structure [36] that is fundamentally different from the 4-rung solenoid model proposed for the CJD-associated resPrP $\mathrm{P}^{\mathrm{D}}[5,37]$. Remarkably, diseased mice inoculated with PrP23-144 fibrils accumulate GSS-like resPrP $\mathrm{P}^{\mathrm{D}}$ aggregates (consisting of $\sim 7 \mathrm{kDa}$ fragment) that likely share the structural motif of amyloid fibrils used as the inoculum [11].

The nature of the covalent crosslinks between PrP fragments and the residues involved in these crosslinks are at present unknown. However, our data strongly suggest that at least two different types of linkages (between different residues) are likely involved in coupling the monomers that form trimers and tetramers, since a single linkage type would preclude mass spectrometric identification of all tryptic fragments from the $\sim 80-150$ region.

Although the basic structural characteristics and mode of aggregation of resPrP ${ }^{\mathrm{D}}$ in $\mathrm{GSS}^{\mathrm{A} 117 \mathrm{~V}}$ and $\mathrm{GSS}^{\mathrm{F} 198 \mathrm{~S}}$ appear to be similar, at least two features distinguish these two conditions. First, substantially more resPrP $\mathrm{P}^{\mathrm{D}}$ populates the hmw regions of the immunoblot in $\mathrm{GSS}^{\mathrm{F} 198 \mathrm{~S}}$ than in GSS $^{\mathrm{A} 117 \mathrm{~V}}$, suggesting a stronger propensity for covalent polymerization in $\mathrm{GSS}^{\mathrm{F} 198 \mathrm{~S}}$. Second, $\operatorname{resPrP}^{\mathrm{D}}$ associated with GSS ${ }^{\mathrm{A} 117 \mathrm{~V}}$ consists solely of fragments containing the $129 \mathrm{~V}$ polymorphic form of $\mathrm{PrP}$, whereas both polymorphs are present in $\mathrm{GSS}^{\mathrm{F} 198 \mathrm{~S}}$, even though the $129 \mathrm{~V}$ form 
predominates. Since pathogenic mutations in both GSS variants are on the background of $129 \mathrm{~V}$ PrP, this implies that resPrP $\mathrm{P}^{\mathrm{D}}$ in $\mathrm{GSS}^{\mathrm{F} 198 \mathrm{~S}}$ contains internal PrP fragments derived both from both the mutant as well as wild-type proteins. By contrast, the internal $\operatorname{PrP}$ fragments populating $\mathrm{GSS}^{\mathrm{A} 117 \mathrm{~V}}$ resPrP ${ }^{\mathrm{D}}$ represent exclusively the mutant protein. This suggests that the A117V mutation (which is within the PK-resistant fragments) may impede the templated conversion of wild type PrP. No such impediment would be expected in $\mathrm{GSS}^{\mathrm{F}}{ }^{198 \mathrm{~S}}$ where the pathogenic mutation is outside the PK-resistant region.

Recently, a novel eight-residue insertion in the hydrophobic region of $\operatorname{PrP}$ has been associated with a GSS phenotype [23]. Brains of transgenic mice harboring the corresponding mouse insertion variation revealed the presence of a $8 \mathrm{kDa}$ resPrP $\mathrm{P}^{\mathrm{D}}$ fragment similar to those observed in other GSS variants as well as a $16 \mathrm{kDa}$ thermolysin-resistant fragment mapping to residues 23-155. Based on this finding and other data, it was suggested that the $8 \mathrm{kDa}$ internal fragment derived from the $\mathrm{N}$-terminal truncation of the $16 \mathrm{kDa}$ fragment and that this mechanism was shared by other GSS variants. While this hypothesis may apply to the mouse model and, possibly, to this specific GSS insertion variant, our demonstration that hmw bands harbor oligomers of the $\sim 7$ and $\sim 8 \mathrm{kDa}$ fragments in $\mathrm{GSS}^{\mathrm{A} 117 \mathrm{~V}}$ and $\mathrm{GSS}^{\mathrm{F} 198 \mathrm{~S}}$ (and possibly GSS $^{\mathrm{H} 187 \mathrm{R}}$ ) makes the proposed mechanism not applicable to these GSS variants.

\section{Conclusion}

We demonstrated for the first time that the formation of multimers of a small internal fragment is the primary mechanism of prion aggregation in GSS ${ }^{\mathrm{A} 117 \mathrm{~V}}$ and GSS ${ }^{\mathrm{F} 198 \mathrm{~S}}$, two classical variants of Gerstmann-Sträussler-Scheinker disease (GSS). Prion aggregation by covalently-linked multimer formation from a small glycan- and GPI-free fragment is likely to allow for novel prion assembles. This finding opens new horizons and likely will stimulate new research. Covalently-linked multimers formation has been reported in other neurodegenerative diseases such as Parkinson's and Alzheimer's diseases.

\section{Additional files}

Additional file 1: Figure S1. Further biochemical characterization of resPrPD associated with GSS ${ }^{\mathrm{F}}{ }^{\mathrm{P}}$. Lane 1: PNGase F-deglycosylated resPrP $P^{D}$ from brain homogenate immunoblotted with 3F4 following standard conditions. Lane 2: with additional boiling, freezing-thawing and sonication pre-deglycosylation; lane 3: 41 h PNGase F treatment; lanes 47: incubation with strong denaturants, $8 \mathrm{M}$ urea (after ethanol or methanol precipitation, lanes 4,5$)$ and $8 \mathrm{M}$ guanidine hydrochloride at $80{ }^{\circ} \mathrm{C}$ (after ethanol or methanol precipitation, lanes 6,7 ) pre-deglycosylation. Treatments had no detectable effect on the resPrP ${ }^{D}$ electrophoretic profile. (TIF $17802 \mathrm{~kb}$ )
Additional file 2: Table S1. Tryptic peptides identified for $\sim 7 \mathrm{KDa}$ band in GSS $^{\mathrm{A} 117 \mathrm{~N}}$ resPrP ${ }^{\mathrm{D}}$. Residue at position 129 is marked in blue. Table S2. Tryptic peptides identified for $\sim 8 \mathrm{KDa}$ band in GSS ${ }^{\mathrm{F} 198 \mathrm{~S}}$ resPrPD . (PDF $122 \mathrm{~kb}$ )

\section{Abbreviations}

Ab: Antibody; BH: Brain homogenates; CJD: Creutzfeldt-Jakob disease; GPI: Glycosylphosphatidylinositol; GSS: Gerstmann-Sträussler-Scheinker disease; hmw: Higher molecular weight; K: Lysine; kDa: Kilodaltons;

M: Methionine; MS: Mass spectrometry; mw: Molecular weight; Nano LC-MS/ MS: Nano liquid chromatography mass spectrometry; NPDPSC: National Prion Disease Pathology Surveillance Center; PK: Proteinase K;

PMSF: Phenylmethanesulfonyl fluoride; PrPD: Disease-related prion protein; PVDF: Polyvinylidene difluoride; R: Arginine; resPrPD: Disease-related proteinase K-resistant prion protein; SDS: Sodium dodecyl sulfate; TBS: Tris buffered saline; $\mathrm{V}$ : Valine

\section{Acknowledgements}

The authors thank the CJD Foundation, the patients' families and the National Prion Disease Pathology Surveillance Center, in particular Brian S. Appleby, MD, NPDPSC Director, as well as Mses. Janis Blevins, Katie Glisic and Mr. Aaron Foutz.

\section{Funding}

This study was supported by the US National Institutes of Health Grants R01 NS083687, P01 Al106705 (to WKS and PG), P01 Al077774 (to PG), R01 NS103848 (to WKS) and The Charles S. Britton Fund (to PG).

\section{Availability of data and materials}

The datasets used and/or analysed during the current study are available from the corresponding author on reasonable request.

\section{Authors' contributions}

Conception and design of the project: LC, WKS, PG. Acquisition of data: LC, $X X, S K N, J L, I C$. Analysis and interpretation of the data: LC, XX, SKN, SN, WKS, PG. Writing of the manuscript: LC, XX, SKN, WKS, PG. Revision of the manuscript: LC, XX, SKN, JL, IC, BG, SN, WKS, PG. All authors read and approved the final manuscript.

Ethics approval and consent to participate

All procedures were performed under protocols approved by the Institutional Review Board at Case Western Reserve University. Written informed consent for research was obtained from all patients or legal guardians according to the Declaration of Helsinki. All patients' data and samples were coded and handled in accordance with NIH guidelines to protect patients' identities.

Consent for publication

Not applicable.

\section{Competing interests}

The authors declare that they have no competing interests.

\section{Publisher's Note}

Springer Nature remains neutral with regard to jurisdictional claims in published maps and institutional affiliations.

\section{Author details}

${ }^{1}$ Department of Pathology, Case Western Reserve University, Cleveland, $\mathrm{OH}$, USA. ${ }^{2}$ Department of Physiology and Biophysics, Case Western Reserve University, Cleveland, OH, USA. ${ }^{3}$ National Prion Disease Pathology Surveillance Center, Case Western Reserve University, Cleveland, OH, USA. ${ }^{4}$ Department of Pathology and Laboratory Medicine, Indiana University School of Medicine, Indianapolis, IN, USA.

Received: 22 April 2019 Accepted: 9 May 2019

Published online: 29 May 2019

\section{References}

1. Aguilar-Calvo P, Xiao X, Bett C, Erana H, Soldau K, Castilla J, Nilsson KP, Surewicz WK, Sigurdson CJ (2017) Post-translational modifications in PrP 
expand the conformational diversity of prions in vivo. Sci Rep 7:43295 https://doi.org/10.1038/srep43295

2. Al-Hilaly YK, Biasetti L, Blakeman BJ, Pollack SJ, Zibaee S, Abdul-Sada A, Thorpe JR, Xue WF, Serpell LC (2016) The involvement of dityrosine crosslinking in alpha-synuclein assembly and deposition in Lewy bodies in Parkinson's disease. Sci Rep 6:39171. https://doi.org/10.1038/srep39171

3. Al-Hilaly YK, Williams TL, Stewart-Parker M, Ford L, Skaria E, Cole M, Bucher WG, Morris KL, Sada AA, Thorpe JR, Serpell LC (2013) A central role for dityrosine crosslinking of amyloid-beta in Alzheimer's disease. Acta Neuropathol Commun 1:83. https://doi.org/10.1186/2051-5960-1-83

4. Bantscheff M, Lemeer S, Savitski MM, Kuster B (2012) Quantitative mass spectrometry in proteomics: critical review update from 2007 to the present Anal Bioanal Chem 404:939-965. https://doi.org/10.1007/s00216-012-6203-4

5. Baskakov IV, Caughey B, Requena JR, Sevillano AM, Surewicz WK, Wille H (2019) The prion 2018 round tables (I): the structure of PrP(Sc). Prion 13:4652. https://doi.org/10.1080/19336896.2019.1569450

6. Bishop MT, Will RG, Manson JC (2010) Defining sporadic Creutzfeldt-Jakob disease strains and their transmission properties. Proc Natl Acad Sci U S A 107:12005-12010. https://doi.org/10.1073/pnas.1004688107

7. Bolton DC, Bendheim PE, Marmorstein AD, Potempska A (1987) Isolation and structural studies of the intact scrapie agent protein. Arch Biochem Biophys 258:579-590

8. Bolton DC, Meyer RK, Prusiner SB (1985) Scrapie PrP 27-30 is a sialoglycoprotein. J Virol 53:596-606

9. Borsarelli CD, Falomir-Lockhart $\sqcup$, Ostatna V, Fauerbach JA, $\mathrm{Hsiao} \mathrm{HH}_{\text {, }}$ Urlaub H, Palecek E, Jares-Erijman EA, Jovin TM (2012) Biophysical properties and cellular toxicity of covalent crosslinked oligomers of alpha-synuclein formed by photoinduced side-chain tyrosyl radicals. Free Radic Biol Med 53: 1004-1015. https://doi.org/10.1016/j.freeradbiomed.2012.06.035

10. Brinkmalm G, Hong W, Wang Z, Liu W, O'Malley TT, Sun X, Frosch MP, Selkoe DJ, Portelius E, Zetterberg H, Blennow K, Walsh DM (2019) Identification of neurotoxic cross-linked amyloid-beta dimers in the Alzheimer's brain. Brain 142:1441-1457. https://doi.org/10.1093/brain/awz066

11. Choi JK, Cali I, Surewicz K, Kong Q, Gambetti P, Surewicz WK (2016) Amyloid fibrils from the N-terminal prion protein fragment are infectious. Proc Natl Acad Sci U S A 113:13851-13856. https://doi.org/10.1073/pnas.1610716113

12. Colucci M, Moleres FJ, Xie ZL, Ray-Chaudhury A, Gutti S, Butefisch CM, Cervenakova L, Wang W, Goldfarb LG, Kong Q, Ghetti B, Chen SG, Gambetti P (2006) Gerstmann-Straussler-Scheinker: a new phenotype with 'curly' PrP deposits. J Neuropathol Exp Neurol 65:642-651. https://doi.org/10.1097/01. jnen.0000228198.81797.4d

13. Cracco L, Notari S, Cali I, Sy MS, Chen SG, Cohen ML, Ghetti B, Appleby BS, Zou WQ, Caughey B, Safar JG, Gambetti P (2017) Novel strain properties distinguishing sporadic prion diseases sharing prion protein genotype and prion type. Sci Rep 7:38280. https://doi.org/10.1038/srep38280

14. Feraudet C, Morel N, Simon S, Volland H, Frobert Y, Creminon C, Vilette D, Lehmann S, Grassi J (2005) Screening of 145 anti-PrP monoclonal antibodies for their capacity to inhibit PrPSC replication in infected cells. J Biol Chem 280:11247-11258. https://doi.org/10.1074/jbc.M407006200

15. Gambetti P, Cali I, Notari S, Kong Q, Zou WQ, Surewicz WK (2011) Molecular biology and pathology of prion strains in sporadic human prion diseases. Acta Neuropathol 121:79-90. https://doi.org/10.1007/ s00401-010-0761-3

16. Gambetti P, Kong Q, Zou W, Parchi P, Chen SG (2003) Sporadic and familial CJD: classification and characterisation. Br Med Bull 66:213-239

17. Ghetti B, Piccardo P, Zanusso G (2018) Dominantly inherited prion protein cerebral amyloidoses - a modern view of Gerstmann-StrausslerScheinker. Handb Clin Neurol 153:243-269. https://doi.org/10.1016/B9780-444-63945-5.00014-3

18. Gretzschel A, Buschmann A, Langeveld J, Groschup MH (2006) Immunological characterization of abnormal prion protein from atypical scrapie cases in sheep using a panel of monoclonal antibodies. J Gen Virol 87:3715-3722. https://doi.org/10.1099/vir.0.81816-0

19. Kascsak RJ, Rubenstein R, Merz PA, Tonna-DeMasi M, Fersko R, Carp RI, Wisniewski HM, Diringer H (1987) Mouse polyclonal and monoclonal antibody to scrapie-associated fibril proteins. J Virol 61:3688-3693

20. Kong Q, Surewicz WK, Petersen RB, et al. (2004). Inherited prion diseases. In: SB Prusiner (Ed.), Prion Biology and Diseases, 2nd edition, Cold Springs Harbor Laboratory Press, New York. p. 673.

21. Ladogana A, Kovacs GG (2018) Genetic Creutzfeldt-Jakob disease. Handb Clin Neurol 153:219-242. https://doi.org/10.1016/B978-0-444-63945-5.00013-1
22. Li R, Liu T, Wong BS, Pan T, Morillas M, Swietnicki W, O'Rourke K, Gambetti P, Surewicz WK, Sy MS (2000) Identification of an epitope in the C terminus of normal prion protein whose expression is modulated by binding events in the N terminus. J Mol Biol 301:567-573. https://doi.org/10.1006/jmbi.2000.3986

23. Mercer RCC, Daude N, Dorosh L, Fu ZL, Mays CE, Gapeshina H, Wohlgemuth SL, Acevedo-Morantes CY, Yang J, Cashman NR, Coulthart MB, Pearson DM, Joseph JT, Wille H, Safar JG, Jansen GH, Stepanova M, Sykes BD, Westaway D (2018) A novel Gerstmann-Straussler-Scheinker disease mutation defines a precursor for amyloidogenic $8 \mathrm{kDa}$ PrP fragments and reveals $\mathrm{N}$-terminal structural changes shared by other GSS alleles. PLoS Pathog 14:e1006826. https://doi.org/10.1371/journal.ppat.1006826

24. Notari S, Strammiello R, Capellari S, Giese A, Cescatti M, Grassi J, Ghetti B, Langeveld JP, Zou WQ, Gambetti P, Kretzschmar HA, Parchi P (2008) Characterization of truncated forms of abnormal prion protein in Creutzfeldt-Jakob disease. J Biol Chem 283:30557-30565. https://doi.org/10. 1074/jbc.M801877200

25. Parchi P, Chen SG, Brown P, Zou W, Capellari S, Budka H, Hainfellner J, Reyes PF, Golden GT, Hauw JJ, Gajdusek DC, Gambetti P (1998) Different patterns of truncated prion protein fragments correlate with distinct phenotypes in P102L Gerstmann-Straussler-Scheinker disease. Proc Natl Acad Sci U S A 95:8322-8327

26. Parchi P, Zou W, Wang W, Brown P, Capellari S, Ghetti B, Kopp N, SchulzSchaeffer WJ, Kretzschmar HA, Head MW, Ironside JW, Gambetti P, Chen SG (2000) Genetic influence on the structural variations of the abnormal prion protein. Proc Natl Acad Sci U S A 97:10168-10172

27. Piccardo P, Liepnieks JJ, William A, Dlouhy SR, Farlow MR, Young K, Nochlin D, Bird TD, Nixon RR, Ball MJ, DeCarli C, Bugiani O, Tagliavini F, Benson MD, Ghetti B (2001) Prion proteins with different conformations accumulate in Gerstmann-Straussler-Scheinker disease caused by A117V and F198S mutations. Am J Pathol 158:2201-2207. https://doi.org/10. 1016/S0002-9440(10)64692-5

28. Pirisinu L, Di Bari MA, D'Agostino C, Marcon S, Riccardi G, Poleggi A, Cohen ML, Appleby BS, Gambetti P, Ghetti B, Agrimi U, Nonno R (2016) GerstmannStraussler-Scheinker disease subtypes efficiently transmit in bank voles as genuine prion diseases. Sci Rep 6:20443. https://doi.org/10.1038/srep20443

29. Priola SA, Caughey B, Wehrly K, Chesebro B (1995) A 60-kDa prion protein (PrP) with properties of both the normal and scrapie-associated forms of PrP. J Biol Chem 270:3299-3305

30. Safar JG, Xiao X, Kabir ME, Chen S, Kim C, Haldiman T, Cohen Y, Chen W, Cohen ML, Surewicz WK (2015) Structural determinants of phenotypic diversity and replication rate of human prions. PLoS Pathog 11:e1004832. https://doi.org/10.1371/journal.ppat.1004832

31. Shevchenko A, Tomas H, Havlis J, Olsen JV, Mann M (2006) In-gel digestion for mass spectrometric characterization of proteins and proteomes. Nat Protoc 1:2856-2860. https://doi.org/10.1038/nprot.2006.468

32. Souza JM, Giasson Bl, Chen Q, Lee VM, Ischiropoulos H (2000) Dityrosine cross-linking promotes formation of stable alpha -synuclein polymers. Implication of nitrative and oxidative stress in the pathogenesis of neurodegenerative synucleinopathies. J Biol Chem 275:18344-18349. https://doi.org/10.1074/jbc.M000206200

33. Tagliavini F, Lievens PM, Tranchant C, Warter JM, Mohr M, Giaccone G, Perini F, Rossi G, Salmona M, Piccardo P, Ghetti B, Beavis RC, Bugiani O, Frangione $B$, Prelli $F$ (2001) A 7-kDa prion protein (PrP) fragment, an integral component of the PrP region required for infectivity, is the major amyloid protein in Gerstmann-Straussler-Scheinker disease A117V. J Biol Chem 276 6009-6015. https://doi.org/10.1074/jbc.M007062200

34. Tagliavini F, Prelli F, Ghiso J, Bugiani O, Serban D, Prusiner SB, Farlow MR, Ghetti B, Frangione B (1991) Amyloid protein of Gerstmann-StrausslerScheinker disease (Indiana kindred) is an $11 \mathrm{kd}$ fragment of prion protein with an N-terminal glycine at codon 58. EMBO J 10:513-519

35. Tagliavini F, Prelli F, Porro M, Rossi G, Giaccone G, Farlow MR, Dlouhy SR, Ghetti B, Bugiani O, Frangione B (1994) Amyloid fibrils in GerstmannStraussler-Scheinker disease (Indiana and Swedish kindreds) express only PrP peptides encoded by the mutant allele. Cell 79:695-703

36. Theint T, Nadaud PS, Aucoin D, Helmus JJ, Pondaven SP, Surewicz K, Surewicz WK, Jaroniec CP (2017) Species-dependent structural polymorphism of Y145Stop prion protein amyloid revealed by solid-state NMR spectroscopy. Nat Commun 8:753. https://doi.org/10.1038/s41467-017-00794-z

37. Vazquez-Fernandez E, Vos MR, Afanasyev P, Cebey L, Sevillano AM, Vidal E, Rosa I, Renault L, Ramos A, Peters PJ, Fernandez JJ, van Heel M, Young HS, Requena JR, Wille $H$ (2016) The structural architecture of an infectious 
mammalian prion using Electron Cryomicroscopy. PLoS Pathog 12: e1005835. https://doi.org/10.1371/journal.ppat.1005835

38. Vorberg I, Buschmann A, Harmeyer S, Saalmuller A, Pfaff E, Groschup MH (1999) A novel epitope for the specific detection of exogenous prion proteins in transgenic mice and transfected murine cell lines. Virology 255: 26-31. https://doi.org/10.1006/viro.1998.9561

39. Zerr I, Parchi P (2018) Sporadic Creutzfeldt-Jakob disease. Handb Clin Neurol 153:155-174. https://doi.org/10.1016/B978-0-444-63945-5.00009-X

40. Zou W, Colucci M, Gambetti P, Chen SG (2003) Characterization of prion proteins. in: Methods in Molecular Biology-Neurogenetics: Methods and Protocols. Edited by Potter, N.T., pp. 305-314. Humana Press Inc., Totowa. 2002

41. Zou WQ, Capellari S, Parchi P, Sy MS, Gambetti P, Chen SG (2003) Identification of novel proteinase K-resistant C-terminal fragments of PrP in Creutzfeldt-Jakob disease. J Biol Chem 278:40429-40436. https://doi. org/10.1074/jbc.M308550200

42. Zou WQ, Langeveld J, Xiao X, Chen S, McGeer PL, Yuan J, Payne MC, Kang HE, McGeehan J, Sy MS, Greenspan NS, Kaplan D, Wang GX, Parchi P, Hoover E, Kneale G, Telling G, Surewicz WK, Kong Q, Guo JP (2010) PrP conformational transitions alter species preference of a PrP-specific antibody. J Biol Chem 285: 13874-13884. https://doi.org/10.1074/jbc.M109.088831

Ready to submit your research? Choose BMC and benefit from:

- fast, convenient online submission

- thorough peer review by experienced researchers in your field

- rapid publication on acceptance

- support for research data, including large and complex data types

- gold Open Access which fosters wider collaboration and increased citations

- maximum visibility for your research: over $100 \mathrm{M}$ website views per year

At BMC, research is always in progress.

Learn more biomedcentral.com/submissions 